\section{Palms on the Edge: Species and Strategies for Landscape Utilization}

\author{
Garry V. McDonald ${ }^{1,4}$, Michael A. Schnelle ${ }^{2}$, \\ and Michael A. Arnold ${ }^{3}$
}

Additional index words. Arecaceae, Palmae, cold temperature tolerance, microclimate

Summary. An emerging niche in landscape design is the creation of exotic venues in commercial and residential settings using unusual plant materials. For instance, the creation of a tropical looking pool area at a hotel, a southwestern desert look for a Mexican restaurant or an oasis for the consumer at a shopping venue can all be in part achieved by the addition of specific plants. Palms (Arecaceae) can be an important component of this effort, even in temperate landscapes. This article focuses on issues related to the incorporation of palms in temperate landscapes. Although palms are signature plants of tropical regions, a surprising number of species can be grown in U.S. Department of Agriculture cold hardiness zones 8, 7, or colder via a combination of appropriate genotype selection, attention to microclimates in design specifications, and/or special cultural practices to mitigate the impact of cold temperatures. Cold-tolerant palms can be a critical design element, especially when paired with other lush tropical-appearing plants, to achieve the goal of creating the illusion of an exotic tropical locale in temperate-climate landscapes. Genotypic and site specification, careful attention to establishment requirements, and modified maintenance practices are critical determinants for success that will be addressed.

$\mathrm{P}$ alms used in the landscape can create a tropical ambiance and are commonly used around commercial, retail, and private properties in the southern United States, particularly along the coast from Virginia to Texas and in the southwestern United States and in many parts of California. They are especially popular around swimming pools and sun deck areas at hotels and resorts (Arnold, 2008). Palms are also extensively used around many ethnic food restaurants, such as those with Mexican or Caribbean cuisine, to create an atmosphere indicative of more

The authors wish to thank Dr. Brent Pemberton for the use of his images.

Mention of a trademark, proprietary product, or vendor does not constitute a guarantee or warranty of the product by the authors or the University of Arkansas, Oklahoma State University, or Texas A\&M University, and does not imply its approval to the exclusion of other products or vendors that also may be suitable.

${ }^{1}$ Assistant Professor of Landscape Horticulture, 316 Plant Science Building, Department of Horticulture, University of Arkansas, Fayetteville, AR 72701

${ }^{2}$ Professor and Extension Ornamentals/Floriculture Specialist, Horticulture and Landscape Architecture Department, 358 AG Hall, Stillwater, OK 7407806027

${ }^{3}$ Professor of Landscape Horticulture, Texas A\&M University, Department of Horticultural Sciences, 207 Horticulture/Forestry Sciences Building, College Station, TX 77843-2133

${ }^{4}$ Corresponding author. E-mail: gmcdonal@uark.edu. tropical areas (Arnold, 2008). In addition, many homeowners use palms in the landscape to lend an exotic feel to backyard entertainment areas or to stress the southern vernacular (Riffle, 1998; Riffle and Craft, 2003).

Studies investigating temperature trends in Texas and the southwestern United States from the years 1941 to 2000 show an overall warming trend post-1970 (Englehart and Douglas, 2003). Warmer winters associated with this trend have encouraged palm plantings away from the immediate Gulf Coastal areas into areas as far north as the Dallas-Ft. Worth metroplex in Texas [U.S. Department of Agriculture (USDA) Plant Hardiness Zones 8a-7b (USDA, 1990)] central and eastern Oklahoma (Zones $7 \mathrm{a}$ and $7 \mathrm{~b}$ ), central Arkansas (Zone 7a), and across the upper southern United States to the Atlantic seaboard. For instance, in College Station, TX, which is listed as USDA Zone $8 \mathrm{~b}$, plantings of queen palm (Syagrus romanzoffiana) and chinese fan palm (Livistona chinensis) have been used in many commercial landscape projects, whereas these species were once foreign to landscapes outside of the immediate Gulf Coast or the Houston, TX, metropolitan area before 1990 (G.V. McDonald, personal observations). California fan palm (Washingtonia filifera) and jelly palm (Butia capitata) have been successfully planted in northeastern Texas (Zones 7b and 8a) at several sites since the early 1990s (G.V. McDonald, personal observations). In fact, jelly palm usually exhibits poor growth in areas lacking distinct cooler winter temperatures such as southern Florida and the lower Rio Grande Valley of Texas (Arnold, 2008; Riffle, 1998). Another important factor in the expanded range in which palms are planted is the heat island effect associated with large urban areas. Heat islands are highly developed areas that are hotter than nearby rural areas. It has been reported that the annual mean temperature of a city with a population exceeding one million people can be 1 to $3{ }^{\circ} \mathrm{C}$ warmer than surrounding areas (Englehart and Douglas, 2003). An even greater effect can occur at night when temperatures can be $12{ }^{\circ} \mathrm{C}$ higher than rural areas (Oke, 1987, 1997).

In addition to the california fan palm, which is native to isolated canyons in California and Arizona, other species of palms are indigenous to the southern and southwestern United States and have varying cold tolerance (Table 1). Florida has the greatest variety of native palm species in the United States. (Black, 2003; Little, 1977). The needle palm (Rhapidophyllum bystrix), a native to the southeastern United States, is listed as hardy to USDA zone $6 \mathrm{~b}$ (McClendon et al., 2007). Dwarf palmetto (Sabal minor) has a wide geographic distribution in the United States with provenances and recognized horticultural variants from coastal North Carolina to McCurtin and LeFlore counties of Oklahoma to the hill country region of central Texas (Arnold

\begin{tabular}{llll}
\hline Units & & \\
$\begin{array}{l}\text { To convert U.S. to SI, } \\
\text { multiply by }\end{array}$ & U.S. unit & SI unit & $\begin{array}{l}\text { To convert SI to U.S., } \\
\text { multiply by }\end{array}$ \\
\hline$\left({ }^{\circ} \mathrm{F}-32\right) \div 1.8$ & ${ }^{\circ} \mathrm{F}$ & ${ }^{\circ} \mathrm{C}$ & $\left(1.8 \times{ }^{\circ} \mathrm{C}\right)+32$
\end{tabular}

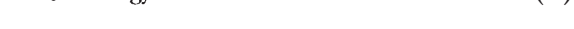


Table 1. Palm species native to the continental United States with associated USDA plant hardiness zone rating and native range.

\begin{tabular}{llcl}
\hline Common name & \multicolumn{1}{c}{ Scientific name } & Zone rating & Native range \\
\hline Everglades palmetto & Accolrrhaphe wrightii & $8 \mathrm{~b}$ & Florida \\
Florida silver palm & Coccothrinax argentata & $9 \mathrm{~b}$ & Florida \\
Keys thatch palm & Lencothrinax morrisii & $9 \mathrm{~b}$ & Florida \\
Needle palm & Rhapidophyllum hystrix & $6 \mathrm{~b}$ & Alabama, Florida, Georgia \\
Florida royal palm & Roystonea regia & $9 \mathrm{a}$ & Florida \\
Scrub palmetto & Sabal etonia & $7 \mathrm{~b}$ & Florida \\
Texas palmetto & Sabal mexicana & $8 \mathrm{~b}$ & Texas \\
Dwarf palmetto & Sabal minor & $7 \mathrm{a}$ & Alabama, Arkansas, Florida, Georgia, Louisiana, \\
& & & Mississippi, North Carolina, Oklahoma, Texas, \\
& & $8 \mathrm{a}$ & South Carolina \\
Cabbage palm & Sabal palmetto & $8 \mathrm{a}$ & Florida, Georgia, South Carolina, North Carolina \\
Saw palmetto & Serenoa repens & 9 & Alabama, Florida, Georgia, Mississippi \\
Florida thatch palm & Thrinax radiata & 9 & Florida \\
California fan palm & Washingtonia filifera & Arizona, California \\
\hline
\end{tabular}

Table 2. Palm species commonly used in cool or temperate landscape plantings and associated USDA plant hardiness zone ratings.

\begin{tabular}{llc}
\hline Common name & \multicolumn{1}{c}{ Scientific name } & Zone rating \\
\hline Blue hesper palm & Brabea armata & $8 \mathrm{a}$ \\
Jelly palm & Butia capitata & $8 \mathrm{~b}$ \\
Mule palm & $\times$ Butyagrus nabonnandii & $8 \mathrm{~b}$ \\
Bamboo palm & Chamaedorea spp. & $8 \mathrm{~b}$ \\
Mediterranean fan palm & Chamaerops humilis & $8 \mathrm{a}$ \\
Chilean wine palm & Jubaea chilensis & $8 \mathrm{a}$ \\
Mazari palm & Nannorrhops ritchiana & $8 \mathrm{a}$ \\
Canary island date palm & Phoenix canariensis & $8 \mathrm{~b}$ \\
Date palm & Phoenix dactylifera & $8 \mathrm{~b}$ \\
Needle palm & Rhapidophyllum hystrix & $7 \mathrm{a}$ \\
Texas palmetto & Sabal mexicana & $8 \mathrm{a}$ \\
Dwarf palmetto & Sabal minor & $7 \mathrm{a}$ \\
Cabbage palm & Sabal palmetto & $8 \mathrm{a}$ \\
Saw palmetto & Serenoa repens & $8 \mathrm{a}$ \\
Queen palm & Syagrus romanzoffiana & $9 \mathrm{a}$ \\
Windmill palm & Trachycarpus fortunei & $7 \mathrm{~b}$ \\
Mexican fan palm & Washingtonia filifera & $8 \mathrm{a}$ \\
& Washingtonia robusta & $9 \mathrm{a}$ \\
\hline
\end{tabular}

2008; Little, 1977; McClendon et al., 2007; Vines, 1960). The increased use in palms grown outside traditional areas has generated inquiries about cold-hardy species, and their management and incorporation into landscape design. This article describes species that are cold hardy to at least USDA Zone 8 and gives recommendations on management and cold protection in marginal climatic areas.

\section{Cold-hardy landscape species}

It has been estimated that as many as 100 species of palms will tolerate temperatures as low as $20^{\circ} \mathrm{F}$ (Frankco, 2003). Selected palm species grown in warm to cool temperate regions and their reported cold hardiness are provided in Table 2 (Arnold 2008; McClendon et al., 2007). This species list is not exhaustive, but represents palm species that are being grown commercially and thus available to the landscape industry and homeowners. Microclimates, heat islands, or protected areas may allow some species to be grown outside their stated hardiness zones. Other species may be found to have cold tolerance greater than reported due to heat island effects or local microclimates. "Heroic" efforts, such as portable greenhouses and heating tapes, are also employed to grow palms far outside the normally accepted range for a given species, but these efforts are not always practical nor recommended for typical landscape situations. Other species may prove to have cold tolerance, but because of lack of seed, poor germination, slow growth, or other factors such as expense, are hard to find commercially and are usually limited to palm enthusiasts' collections.

The use of palms in landscape designs is often grouped according to leaf morphology or growth habit (Arnold, 2008). Typical groupings by leaf morphology would include feather palms (pinnate leaves) versus fan palms (palmate or costapalmate leaves). Among the most commonly grown cold-hardy feather palms readily available in the U.S. nursery trade are jelly palm, mule palm, date palm, and canary island date palm (Tables 1 and 2; Fig. 1). Generally speaking, the jelly palm is the most cold tolerant of these feather palms (Arnold, 2008). Among the most cold hardy of the commonly available fan palms are the needle palm, dwarf palmetto, windmill palm, cabbage palm, mediterranean fan palm, and texas palmetto (Tables 1 and 2; Fig. 2). Some of the most cold-hardy palms, such as needle palm and the dwarf palmetto, have only short trunks or fronds that arise at or near ground level (Arnold, 2008). These short palms have their apical meristems (growing points) near the soil, which is presumed to help in insulting them from cold temperatures compared with exposed buds positioned high above the ground in taller palms. However, there is no correlation of trunk height with hardiness as arborescent 

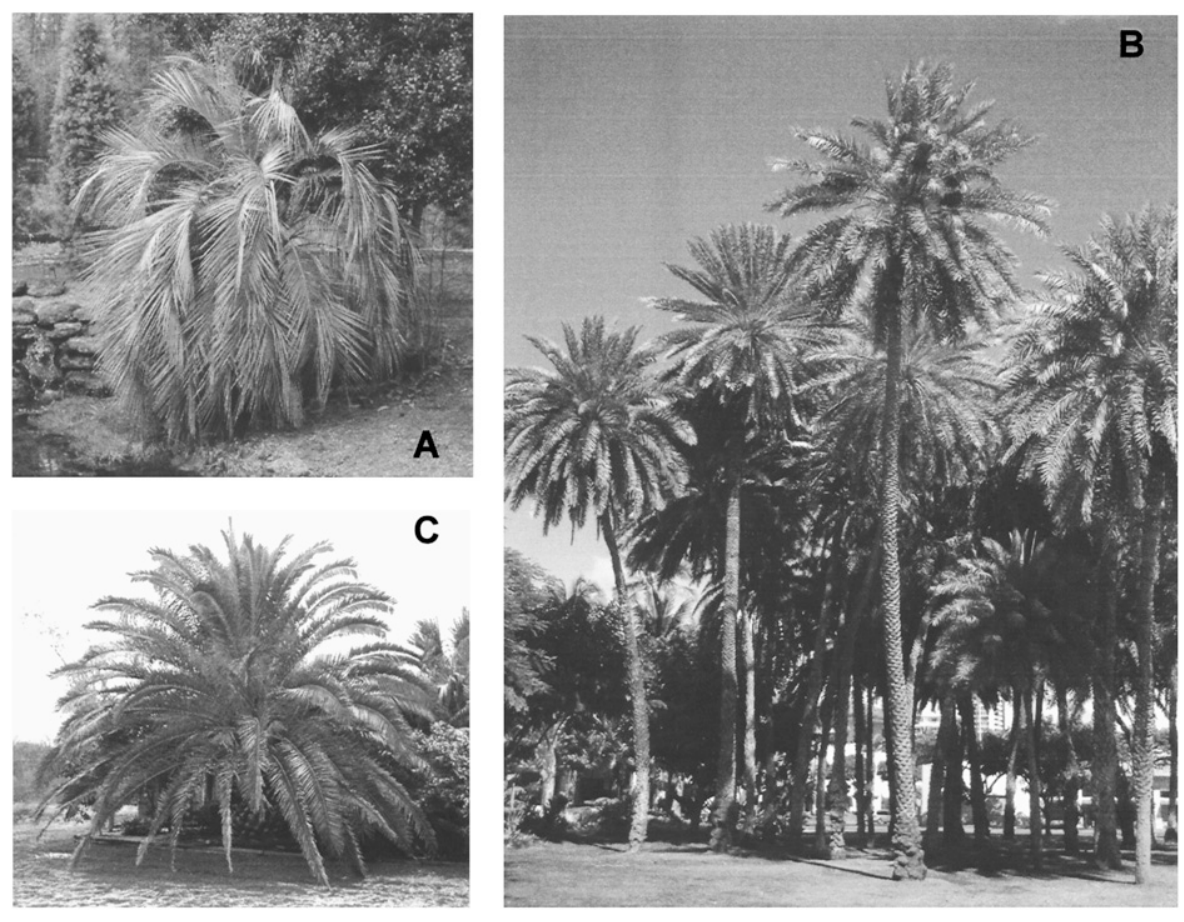

Fig. 1. Commonly grown cold-hardy feather palms readily available in the U.S. nursery trade are jelly palm (A), date palm (B), and canary island date palm (C). Images copyrighted by M.A. Arnold.

cold-hardy palms such as the windmill palm, cabbage palm, or texas palmetto that can be grown in USDA plant hardiness zones 7 or 8 (Tables 1 and 2). There are even cold-hardy palms with multiple trunks, such as mediterranean fan palm and mazari palm (Nannorrhops ritchiana) (Fig. 3).

Selection of provenances from colder portions of marginal species ranges or little-known species that may prove cold hardy are beginning to enter the U.S. landscape trade, such as the kumaon palm (Trachycarpus takil) from the Himalayan region of India. These genotypes may offer even greater diversity of coldhardy selections in the coming years for landscape designers. There are many examples of trees grown for forestry purposes where provenances from high latitudes or high elevations have been used to extend the use of species to colder environments than is typical for the species (Zobel et al., 1987). There would appear to be good potential for this strategy to be employed to identify genotypes of native and exotic species of palms for which their reliable use could be extended to more northern locations in U.S. landscapes.

\section{Factors affecting cold tolerance}

Many factors can influence cold hardiness in palms (Ingram and Yeager, 1982, Ingram et al., 1985). These factors include acclimation, cool down conditioning, and mineral nutritional status. Duration of cold may be as important as the absolute minimum temperature exposure in determining survival. Certain palm species may be able to survive low temperatures of a short duration. Humidity and precipitation levels can also have an effect, with many palms from semiarid regions succumbing to subfreezing temperatures in the humid, higher rainfall southeastern United States, while remaining unaffected at similar subfreezing temperatures in semiarid climates such as northern and central Texas and eastern Oklahoma (McClendon et al., 2007). The mazari palms (Frankco, 2003) and california fan palms (Arnold, 2008) are examples of palms that survive winters better in drier climates. A site with good air drainage with the avoidance of frost pockets can mitigate cold temperatures. Another factor affecting survival is the amount of leaf desiccation from high winds that occurs when root uptake of water is minimum during cold temperatures.

\section{Mitigating cold damage to palms}

Proper species selection is the best way to ensure survival of palms in colder climates, and the correct species may vary with regions that have the same USDA plant hardiness zone rating (Arnold, 2008). Of similar importance is the selection of the correct site and microclimate in the landscape, which can affect palm survival in marginal areas (Francko, 2000). Placing plants on the south side of a wall or in courtyards can trap radiant heat from the sun and therefore reduce the amount of time a palm is exposed to subfreezing temperatures. Walls, evergreen hedges, or overhead tree canopies can provide windbreaks to minimize wind exposure and reduce leaf desiccation damage. Avoid planting palms in low areas where poor air drainage may form frost pockets.

Active winter protection techniques can include simple shelters, wind barriers, natural insulation materials, trunk and/or foliar wrapping, temporary greenhouses, and various heating devices (Frankco, 2003). Simple shelters include placing a blanket or plastic bubble sheeting over the palm. Wind barriers, such as burlap or landscape fabric supported around a palm can reduce desiccating winds. Wind barriers or simple shelters can be augmented by placing loose mulch or other loose insulating materials around the palm. When such a technique is used, some sources cite spraying the stem and bud with a broad spectrum fungicide and/or bactericide to reduce chances of bud rot (Frankco, 2003). Layering accumulated pruned dead palm leaves in an overlapping thatched-roof or "tiki hut" pattern can help to divert rainfall and snow or ice melt from collecting in crevices in the bud and immature spear leaves where repeated freezing and thawing may damage tissues leading to crown rots.

More elaborate cold protection methods such as trunk and foliar wrapping or heating trunks or even the whole plant using a temporary greenhouse can be effective for important specimen palms, but will require much more effort and expense 

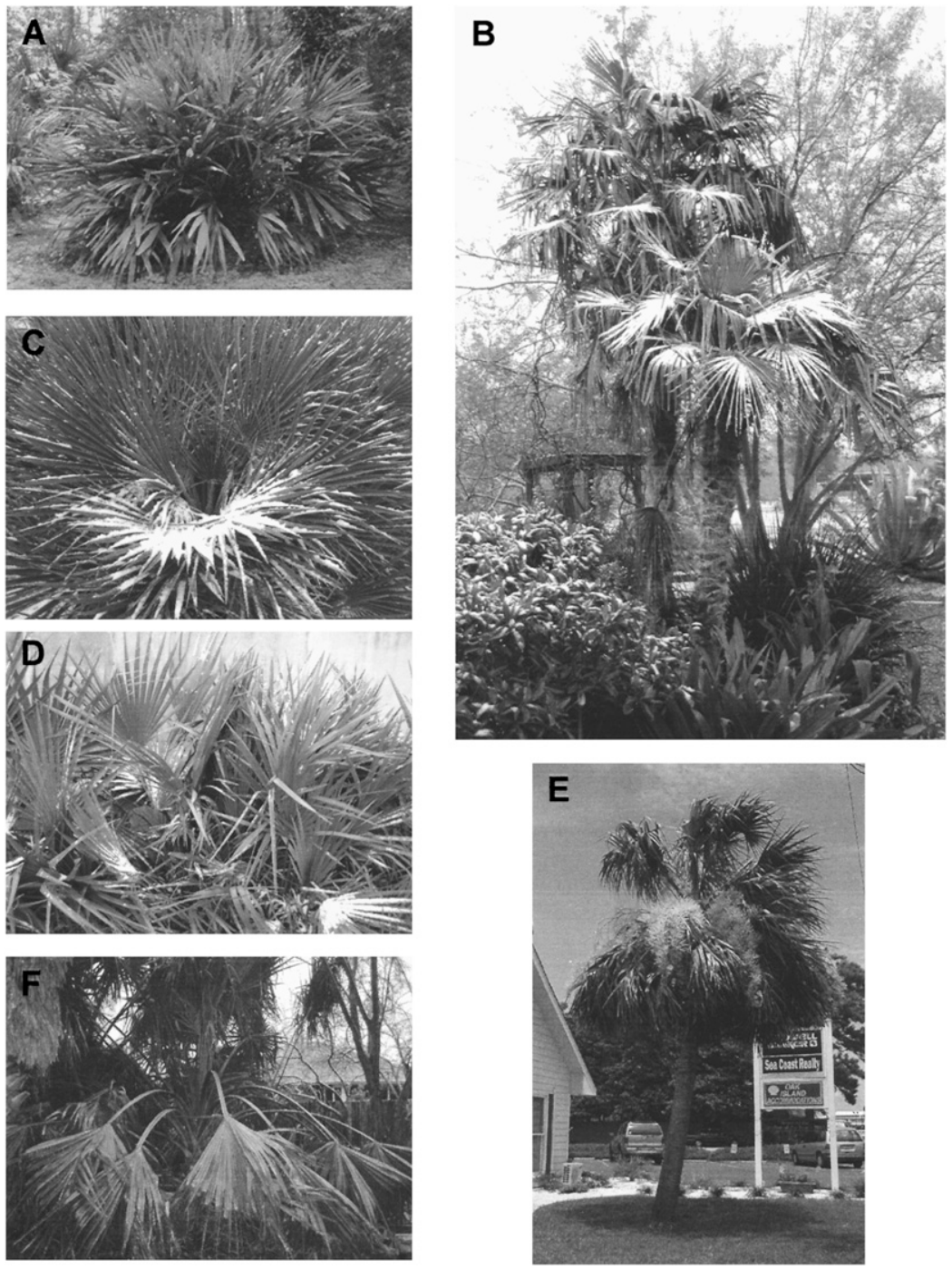

Fig. 2. Commonly grown cold-hardy fan palms are the needle palm (A), windmill palm (B), mediterranean fan palm (C), dwarf palmetto (D), cabbage palm (E), and texas palmetto (F). Images copyrighted by M.A. Arnold.
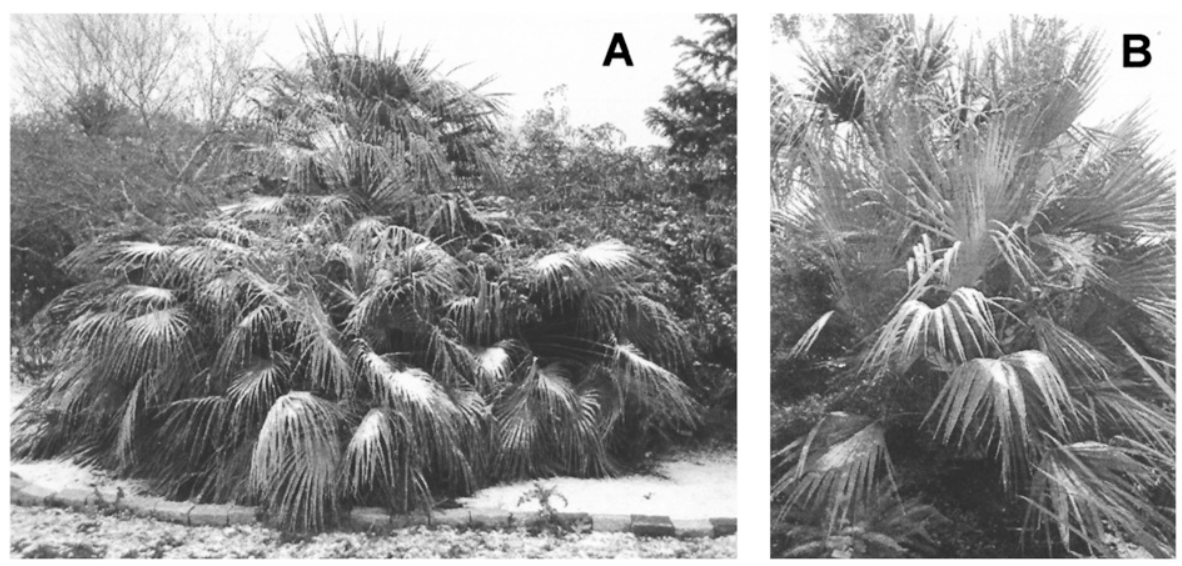

Fig. 3. Cold-hardy palms with multiple trunks, such as mediterranean fan palm (A) and mazari palm (B). Images copywrited by M.A. Arnold.
(Frankco, 2003). It is critical to protect the trunk and apical meristem point, as most palms species have a single growing point per trunk. Once this growing point is damaged or killed, palms do not typically produce the adventitious buds that allow many dicotyledonous trees and shrubs to recover from severe cold damage (Arnold, 2008). Trunks and growing points can be wrapped with a variety of insulating materials (Fig. 4, A-C). Palm leaves are often tied up in a tight bunch around and above the growing point to help insulate the apical meristem and to prevent desiccation of the leaves (Fig. 4C). Heating pads, heat tape or pipe wraps, low wattage heat cables, or strings of lights can be used for high value or prominent specimens. Frankco and Wilhoite (2002) report that strings of C9 lights alone wrapped around palms can add 1 to $2{ }^{\circ} \mathrm{C}$ to the ambient air temperature and that using them under insulating wrap increases the temperatures 6 to $9^{\circ} \mathrm{C}$.

Of course, temporary greenhouses ranging from plastic covers with a light bulb to more elaborate portable glass or plastic structures can be highly effective in sheltering palms during cold temperatures. One advantage of such structures is that they may also provide some heat to the root zone (Frankco, 2003). Avoiding frozen soils will help to ensure moisture flow to the leaves, reducing the chances for desiccation damage.

Future opportunities for incorporation of palms in cooler climate landscapes appear favorable as new introductions, from underused species to more cold-hardy provenance selections from more commonly grown species, are introduced to the trade. Various maintenance practices can be implemented to expand these design possibilities even further. Nearly all palms can be successfully established in at least one cold hardiness zone lower (colder) through securing a microclimate and utilization of other techniques described above. Cold-hardy palms add a unique character to landscapes than cannot be duplicated with other species, resulting in a greatly expanded plant palette for landscape designers and architects, and creating a new niche market for the nursery industry. 

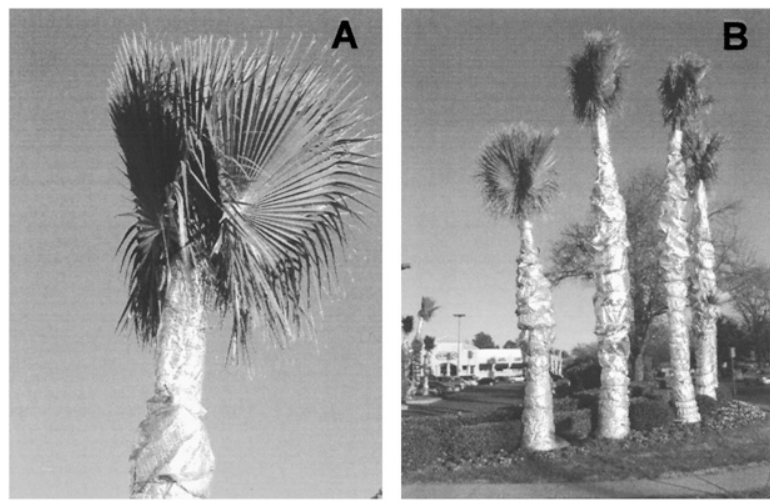

Fig. 4. Mexican fan palm trunks (A) and apical meristems (B) can be wrapped with a variety of insulating materials. Tying the leaves up around the apical meristem (C) can also be used to help protect the growing point and minimize desiccation damage. Images courtesy of H.B. Pemberton.

\section{Literature cited}

Arnold, M.A. 2008. Landscape plants for Texas and environs, 3rd ed. Stipes Publishing, Champaign, IL.

Black, R.J. 2003. Native Florida plants for home landscapes. Inst. Food Agr. Sci., Univ. Florida, Dept. Environ. Hort. Fact Sheet ENH-25.

Englehart, P.J. and A.V. Douglas. 2003. Urbanization and seasonal temperature trends: Observational evidence from a data-sparse part of North America. Int. J. Climatol. 23(10):1253-1263.

Francko, D.A. 2000. Effect of microclimate variation on cultivation of cold-

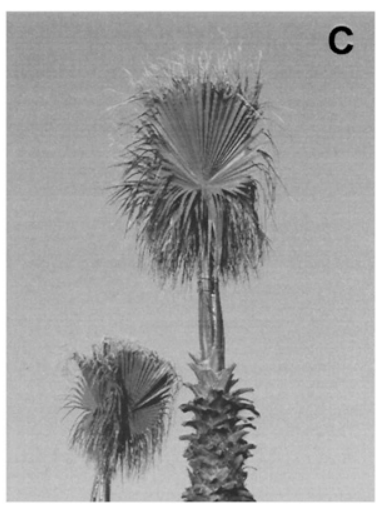

Ingram, D.L., T.H. Yeager, and R.L. Hummel. 1985. Cold protection for nursery crops. Inst. Food Agr. Sci., Univ. Florida, Bul. 201.

Little, E.L., Jr. 1977. Atlas of United States trees. Vol. 4. Minor eastern hardwoods. U.S. Dept. Agr. Misc. Publ. 1342.

McClendon, T., W. Roberds, and J. LeVert. 2007. Hardy palms for the Southeast. Southeastern Palm Soc., Apison, TN.

Oke, T.R. 1987. Boundary layer climates. Routledge, London.

Oke, T.R. 1997. Urban climates and global environmental change, p. 273 287. In: R.D. Thompson and A. Perry (eds.). Applied climatology: Principles and practices. Routledge, London.

Riffle, R.L. 1998. The tropical look: An encyclopedia of dramatic landscape plants. Timber Press, Portland, OR. 44(1):37-46.

Frankco, D.A. 2003. Palms won't grow here and other myths: Warm-climate plants for cooler areas. Timber Press, Portland, OR.

Frankco, D.A. and S. Wilhoite. 2002. Cold-hardy palms in southwestern Ohio: Winter damage, mortality, and recovery. Palms 46(1):5-13.

Ingram, D.L. and T.H. Yeager. 1982. Cold protection of ornamental plants. Inst. Food Agr. Sci., Univ. Florida, Dept. Ornamental Hort. Fact Sheet OH-1.
Riffle, R.L. and P. Craft. 2003. An encyclopedia of cultivated palms. Timber Press, Portland, OR.

U.S. Department of Agriculture. 1990. USDA plant hardiness zone map. U.S. Dept. Agr. Misc. Publ. No. 1475.

Vines, R.A. 1960. Trees, shrubs, and woody vines of the Southwest. Univ. Texas Press, Austin, TX.

Zobel, B.J., G. van Wyr, and P. Stahl. 1987. Growing exotic forests. Wiley, New York. 